\title{
Limite de détection du THC dans les cheveux dans le contexte de l'aptitude à la conduite
}

\section{Cut-off for THC in hair in context of driving ability}

Fritz PRAGST, Thomas NADULSKI

Institute of Legal Medicine, University Hospital Charité, Hittorfst. 18, D-14195 Berlin - Germany

\section{$R E ́ S U M E ́$}

En Allemagne, la consommation régulière de cannabinoïdes est incompatible avec la possession d'un permis de conduire. Ainsi, l'analyse des cheveux est régulièrement utilisée dans le contexte de l'examen d'aptitude à la conduite. Selon les recommandations de la Society of Hair Testing (SoHT), la Gesellschaft für Toxicologie und forensiche Chemie $(G T F C h)$ et la Société Française de Toxicologie Analytique (SFTA), une valeur limite de 0,1 ng/mg de THC dans les cheveux est appliquée. Dans cette présentation, les résultats de l'analyse des cheveux pour le THC obtenus à l'Institut de Médecine Légale de la Charité (Berlin, Allemagne) dans le contexte de l'examen de l'aptitude à la conduite ont été évalués. Parmi 625 échantillons de cheveux étudiés, 453 étaient négatifs. D'autre part, en utilisant une valeur limite de $0,1 \mathrm{ng} / \mathrm{mg}, 47 \%$ des 172 cas positifs avec une concentration de THC détectée sans ambiguïté, ont été rendus négatifs. Par comparaison avec les statistiques de la consommation de Cannabis en Allemagne et du fait que toutes les personnes testées avaient un historique de consommation de Cannabis, cette proportion est très grande. Par conséquent, il a été proposé d'abaisser la limite à $0,05 \mathrm{ng} / \mathrm{mg}$. En outre, il a été montré que les dosages effectués sur des échantillons de cheveux plus courts que les $6 \mathrm{~cm}$ habituels n'avaient pas d'effet essentiel sur la proportion de résultats positifs.

\section{SUMMARY}

In Germany, habitual use of cannabinoids is incompatible with possession of a driving license. Therefore, hair analysis is regularly used in context of the driving ability examination. According to the recommendations of the Society of Hair Testing (SoHT), the Society of Toxicological and. Forensic Chemistry (GTFCh) and the Société Française de Toxicologie Analytique (SFTA), a cut-off value of $0.1 \mathrm{ng} / \mathrm{mg}$ THC in hair is applied. In this presentation the results of the hair analysis for THC obtained in the Institute of Legal Medicine of the Charité Berlin in context of driving ability examination were evaluated. From 625 hair samples 453 were negative. In addition to that, using the cut-off of $0.1 \mathrm{ng} / \mathrm{mg}, 47 \%$ of the 172 positive cases with unambiguously detected THC were also decided to be negative. As shown by comparison with the statistics of cannabis use in. Germany and regarding the fact that all test persons had a cannabis history, this portion is very high. Therefore, it is proposed to decrease the cut-off to $0.05 \mathrm{ng} / \mathrm{mg}$. Furthermore, it is shown that the investigation of hair samples shorter than the usual $6 \mathrm{~cm}$ has no essential effect on the portion of positive results. 


\section{Introduction}

According to the actual cannabis legislation in Germany (1), the possession of a driving license is excluded in case of regular (habitual) cannabis use. In case of occasional cannabis use, a driving license can be issued if the applicant is able to separate (in time) between cannabis use and driving. The driving license is generally not issued if cannabis is consumed in combination with alcohol or other illicit drugs. A suspicion about driving inability because of cannabis abuse arises if there is evidence at the police that the applicant was in possession of cannabis products (two or more times small amounts or once large amounts), that he used cannabis without context to driving or that he was under the influence of cannabis whilst driving. In principle, three categories of cannabis use must be distinguished:

- Single or altogether a few times use (experimental use). This is without consequences to driving license.

- Occasional use. The frequency of use is not clearly defined, it is everything between experimental and regular use. If an occasional use is assumed, the applicant must undergo a Medical Psychological Investigation (in German "MPU") in order to find out whether he is able to abstain from driving if he has used the drug and vice verse.

- Regular use. There were several controversy opinions about this term (1). It means at least daily or almost daily or more than 200 doses per year. In this case, the driving license is suspended.

The course of events in a case of doubt about driving ability because of cannabis and the role of hair analysis in this process in Berlin is shown in Fig. 1. There is no uniform procedure in the different states of Germany $(2,3)$. The information about a cannabis offence (possession or use with or without context to driving) is forwarded from the police to the public affairs office which is responsible also for issuing or suspension of the driving licenses. In case of a valid license, after 6 months to 2 years a hair expertise is requested. In case of application for a new driving license or for extension of an old one, this is requested without delay. The expertise must be submitted within 1-3 months after request. Usually, the applicant appears as late as possible for hair sampling in the laboratory which performs the analysis and writes the expertise within two weeks. For the decision whether a result is positive or negative, the cut-off of $0.1 \mathrm{ng} / \mathrm{mg} \Delta^{9}$ - tetrahydrocannabinol (THC) in hair is applied. A negative result means that no or only experimental use is assumed but occasional use cannot completely be excluded. This is without further consequences to the driving license. A positive result proves, that the person had contact to cannabis products. The

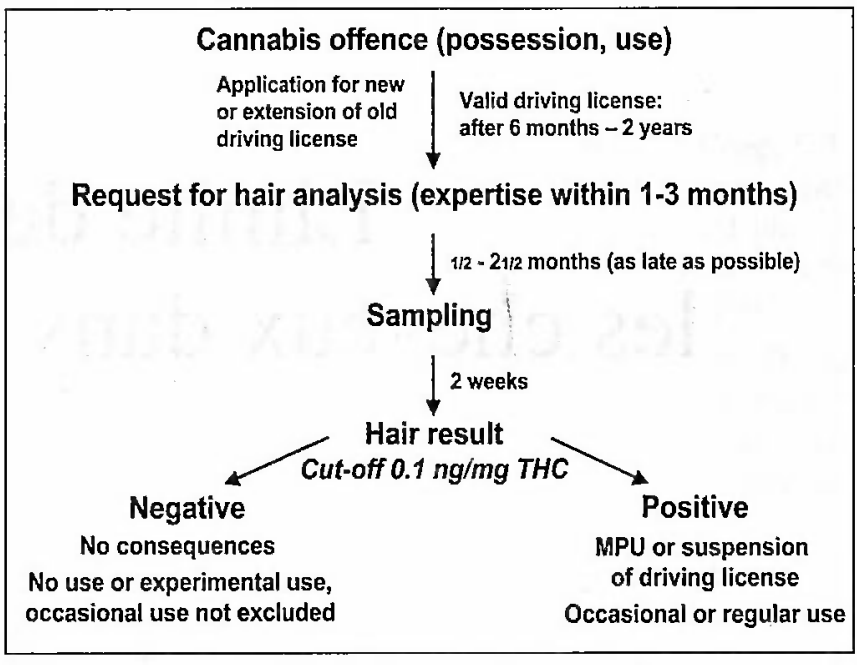

Figure 1 : Course of events in hair testing for THC in context of driving ability examination in Berlin.

concentrations correspond to occasional or even regular use. In this case an MPU is requested or the license is suspended if additional evidence proves regular use.

The cut-off value of $0.1 \mathrm{ng} / \mathrm{mg}$ THC is recommended by the Society of Hair Testing (SoHT) (4), by the Society of Toxicological and Forensic Chemistry (GTFCh) (5) as well as by the Société Française de Toxicologie Analytique (SFTA) (6). In this paper, the hair results of 625 driving ability cases investigated in the Institute of Legal Medicine of the Charité Berlin are compared with the statistics of the marihuana and hashish use in Germany in order to find out whether the cut-off of $0.1 \mathrm{ng} / \mathrm{mg}$ THC in hair is suitable for the described task.

\section{Materials and methods Hair samples}

Hair samples were obtained from 625 test persons who were asked for a hair test by the authorities because of doubtful driving ability after a cannabis offence. 580 (93\%) were male and $45(7 \%)$ female. The age ranged from 17 to 59 years, mean 26 years, $63 \%$ being between 18 and 27 years. Two scalp hair samples (one for analysis and the second in reserve for cases of objection) were collected from each person by cutting directly above the skin from the vertex posterior site. Both samples were separately stored in paper envelopments at room temperature until analysis. Samples longer than $6 \mathrm{~cm}$ were fixed by a string and only the proximal segment 0-6 cm was investigated. Samples shorter than $6 \mathrm{~cm}$ were analyzed in full length.

During the time of this study, the method for determination of cannabinoids from hair was changed. Therefore, both methods are briefly described. 


\section{Determination of THC by extractive derivati- zation with $\mathrm{CH}_{3} \mathrm{I}$}

This procedure was adapted to a method described by Moeller et al. for serum $(7,8)$. After washing with water and acetone and cutting to small pieces, 30-50 mg hair were digested in $1 \mathrm{ml} 1 \mathrm{~N} \mathrm{NaOH}+20 \mathrm{ng} \mathrm{D_{3 }}$-THC (internal standard, $20 \mu \mathrm{l}$ of a $1 \mu \mathrm{g} / \mathrm{ml}$ solution in methanol) for $20 \mathrm{~min}$ at $80{ }^{\circ} \mathrm{C}$. The solution was twice extracted with $\mathrm{n}$-hexane/ethyl acetate $(9: 1 \mathrm{v} / \mathrm{v}, 2 \mathrm{ml}$ and $1 \mathrm{ml}$ ). After evaporation of the solvent at $40^{\circ} \mathrm{C}$ in nitrogen stream, $200 \mu \mathrm{l}$ dimethyl sulphoxide, $50 \mu \mathrm{l}$ tetrabutylammonium hydroxide $\left(20 \%\right.$ in $\left.\mathrm{H}_{2} \mathrm{O}\right)$ and $50 \mu \mathrm{l} \mathrm{CH}_{3} \mathrm{I}$ were added to the residue. The mixture was vortexed and let react for $15 \mathrm{~min}$. Then, $200 \mu \mathrm{l} 0.1 \mathrm{~N} \mathrm{HCl}$ and 1 $\mathrm{ml} \mathrm{i}$-octane were added and the mixture was shaken for $10 \mathrm{~min}$. After that, the i-octane phase was separated and evaporated in the nitrogen stream. The residue was dissolved in $40 \mu \mathrm{l}$ ethyl acetate and $2 \mu \mathrm{l}$ were injected for GC-MS-SIM. The following $\mathrm{m} / \mathrm{z}$ were measured: THC 313, 328 and 345, $\mathrm{D}_{3}$-THC 316, 331, 248 (quantifier ions printed italic).The LOD and LOQ were 0,01 and $0.03 \mathrm{ng} / \mathrm{mg}$ respectively.

\section{Determination of THC, $C B D$ and $C B N$ by headspace solid phase microextraction (HS- SPME) and GC-MS}

The experimental details of this method which was developed during the study were described in a previous paper (9). In brief: The hair sample was washed with water and acetone and cut to pieces of 1-2 mm

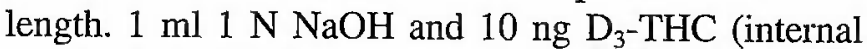
standard) in $10 \mu \mathrm{l}$ methanol were added to $15-30 \mathrm{mg}$ of the sample. After hydrolysis for $20 \mathrm{~min}$ at $80^{\circ} \mathrm{C}$, the analytes were isolated by extraction with $2 \times 2 \mathrm{ml} \mathrm{i}$ octane. The solvent was evaporated in a $10 \mathrm{ml}$ headspace vial at $40{ }^{\circ} \mathrm{C}$ in a nitrogen stream. $10 \mu \mathrm{l}$ bis(trimethylsilyl)trifluoroacetamine (BSTFA) were added to the residue for derivatization. The automatic HS-SPME was performed directly from this mixture for $20 \mathrm{~min}$ at $125{ }^{\circ} \mathrm{C}$ using a $100 \mu \mathrm{m}$ PDMS fiber and a MultiPurposeSampler MPS 2 (Gerstel GmbH, Mühlheim, Germany). The desorption in the injection port of the GC occurred at $280^{\circ} \mathrm{C}$ for $10 \mathrm{~min}$. In the GC-MS-SIM measurement at a HP5-MS capillary column the following $\mathrm{m} / \mathrm{z}$ were used: CBD 351,390 and 458, THC 303, 371 and 386, $\mathrm{D}_{3}$-THC 306,374 and 389 and CBN 310,367 and 382 (the quantifier ion printed italic). In the validation of the method the following LOD and LOQ were determined: THC 0.010 and 0.032 $\mathrm{ng} / \mathrm{mg}, \mathrm{CBD} 0.013$ and $0.038 \mathrm{ng} / \mathrm{mg}$ and $\mathrm{CBN} 0.016$ and $0.048 \mathrm{ng} / \mathrm{mg}$.

In a comparison between both methods including 70 positive samples, a good conformity of the results was found.

\section{Results and Discussion}

In this paper only THC will be considered. CBD and CBN were detected in many of the cases and were used as a qualitative confirmation of the results. From the 625 samples 453 were negative (72\%, THC below LOD) whereas the THC concentrations of 172 samples were between $>$ LOD and $7.72 \mathrm{ng} / \mathrm{mg}$. The statistics is shown in Table I. According to the cut-off $0.1 \mathrm{ng} / \mathrm{mg}$, $47 \%$ of the unambiguously positive results were declared to be negative in the expertise's. Furthermore, the division of the positive samples in Table II into a lower range from $L O D$ to percentile 25 , a medium range from percentile 25 to percentile 75 and an upper range from percentile 75 to maximum shows that the complete lower range is below the cut-off and the median (0.11 $\mathrm{ng} / \mathrm{mg}$ ) is only slightly above the cut-off.

The hair length required for representation of at least 6 months and at maximum 12 months is $6 \mathrm{~cm}$. However, due to the present short hair fashion for male, many of the test persons had hair shorter than $6 \mathrm{~cm}$. Furthermore, it was suspected that in some cases the head was shaved after receiving the request for the test in order to remove positive hair from previous drug use and then let it grow until sampling. In order to use hair analysis still in such cases, it was agreed with the authorities to accept also hair samples shorter than $6 \mathrm{~cm}$. In order to examine whether shorter hair samples have a higher proportion of negative results, the analytical outcome were statistically evaluated with respect

Table I : Distribution of THC concentrations in hair samples.

\begin{tabular}{|lcc|}
\hline & No. of samples & Percentage \\
\hline Total & 625 & 100 \\
Negative & 453 & 72 \\
Positive & 172 & 28 \\
\hline THC, ng/mg & No. of samples & Percentage from pos. samples \\
\hline $0.020-0.050$ & 44 & 25.5 \\
$0.051-0.099$ & 37 & 21.4 \\
\hline $0.10-0.50$ & 57 & 33.1 \\
$0.51-1.00$ & 24 & 14,9 \\
$>1.00$ & 9 & 5.1 \\
\hline
\end{tabular}

Table II : Statistics of THC concentrations in 172 positive hair samples investigated driving ability examination.

\begin{tabular}{|lccc|}
\hline Minimum & Positive (LOD 0.01 ng/mg) \\
Percentile 25 & $0.04 \mathrm{ng} / \mathrm{mg}$ \\
Median & $0.11 \mathrm{ng} / \mathrm{mg}$ \\
Percentile 75 & $0.32 \mathrm{ng} / \mathrm{mg}$ \\
Maximum & $7.72 \mathrm{ng} / \mathrm{mg}$ & Lower range & Medium range \\
\hline
\end{tabular}


to the sample length. As shown in Fig. 2, there is no preference of negative results in the shorter samples. The portion of the positive results is between 24 and $33 \%$ without a noticeable correlation to sample length. Therefore, analysis of samples shorter than $6 \mathrm{~cm}$ is still efficient in driving ability investigation.

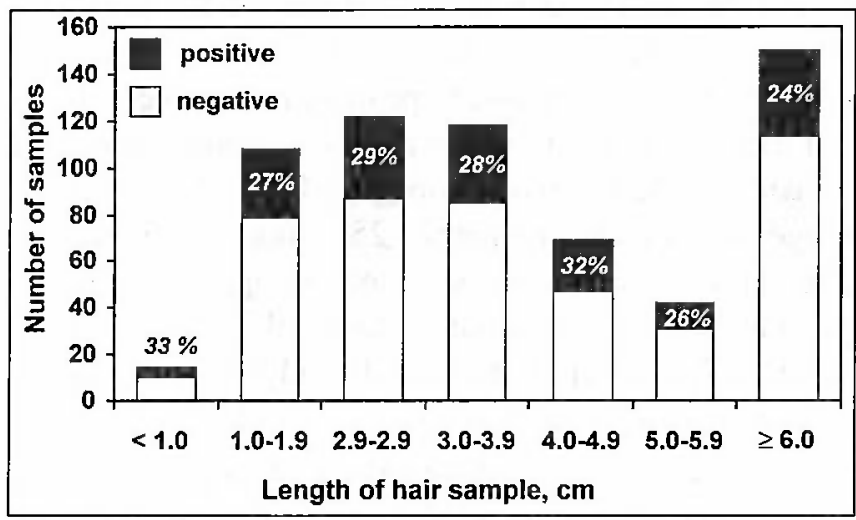

Figure 2 : Influence of hair sample lengths on the outcome of the hair analysis for THC in context driving ability examination in Berlin.

Besides nicotine and alcohol, cannabis is the most abused substance in Germany $(10,11) .31 \%$ of the juveniles (age 12-25) have experience with cannabis. 3.4 million persons used this drug within the last 12 months. 270,000 persons are habitual consumers, and 14,300 persons are in psychiatric treatment because of cannabis abuse. 10,762 confiscation cases were reported by the German police in 2004 . The statistics of the frequency of cannabis use in West Germany in 2000 is shown in Fig. 3. This statistics should approximately also meet the situation in Berlin. About $47 \%$ of the consumers used the drug only between one and five times and can be classified as experimental consumers. $42 \%$ used the drug between 6 and 199 times corresponding to the typical range for occasional consumption. About $11 \%$ had a consumption of more than 200 doses/year and that means regular (daily or almost daily) use.

All of the 625 applicants involved in the present study had a cannabis history and therefore, in a first approximation, should represent the statistics with respect to consumption frequency as it is given in Fig. 3. Therefore, in Fig. 4 the distribution of the hair concentrations of the present study is compared with the general frequency statistics of cannabis use. Although a strong inter-individual correlation between cumulative dose and hair concentration is generally not found, it is assumed in this comparison that, as a mean, very frequent use leads to the highest concentrations whereas experimental use results in the lowest (not detectable) values. It follows from this comparison that by the cutoff of $0.1 \mathrm{ng} / \mathrm{mg}$ only the regular and a relatively small portion of the occasional consumers are detected whereas the overwhelming portion of the occasional consumers remains undiscovered. This was confirmed by several test persons who were surprised by the negative results. This situation could at least partially be improved by lowering the cut-off to $0.05 \mathrm{ng} / \mathrm{mg}$.

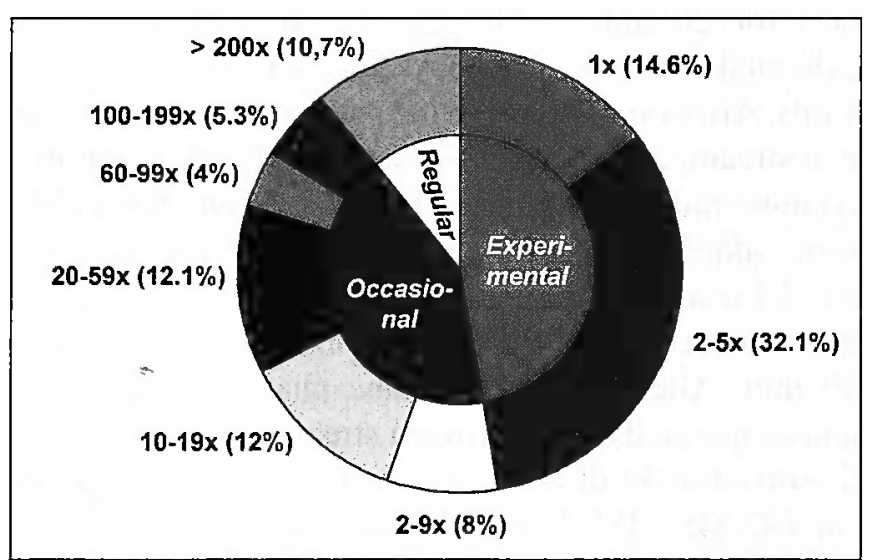

Figure 3 : Statistics of the frequency of cannabis use per year in West Germany in 2000 according to (11) and attribution to experimental, occasional and regular consumption.

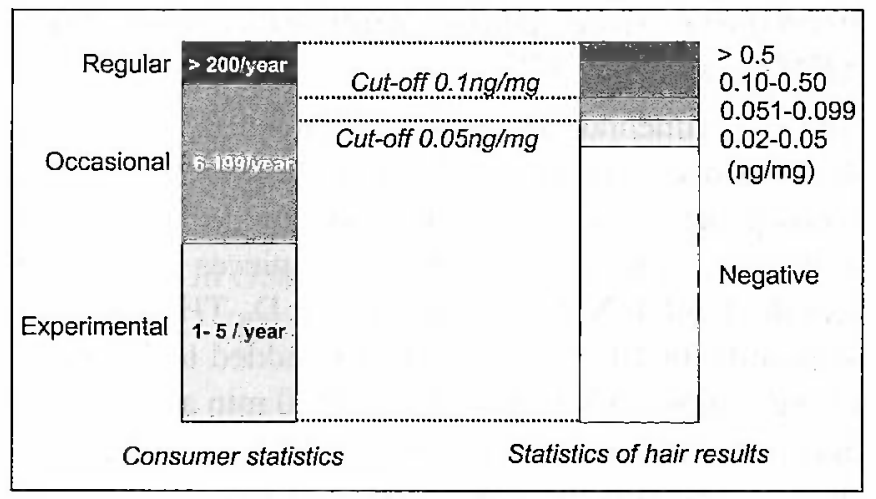

Figure 4 : Comparison of consumer statistics and THC results in hair.

\section{Conclusion}

In driving ability examination, regular and occasional cannabis use should lead to positive hair results. The cut-off value should eliminate single (experimental) use and analytically false positive results. Until now, there are no reliable (e. g. prospective) studies known for evaluation of the consumption frequency with respect to establishing a cut-off. As shown in this paper, it follows from statistical considerations of consumption behavior and hair concentrations that a considerable portion of occasional users is not detected with a cutoff of $0.1 \mathrm{ng} / \mathrm{mg}$ THC in hair. Therefore, it is proposed to decrease the cut-off to $0.05 \mathrm{ng} / \mathrm{mg}$ THC in hair. A. prerequisite is that the method is sufficiently sensitive. The detection of CBD and CBN should be used for confirmation of the results. 


\section{References}

1. V. Kalus. Verwaltungsrecht. In: M. Hettenbach, V. Kalus, M.R. Möller, A. Uhle. Drogen und Straßenverkehr. Deutscher Anwalt Verlag, Bonn (2005), pp. 149-261.

2. H. Sachs and F. Pragst Chemisch-toxikologische Untersuchungen auf illegale Drogen im Rahmen der Fahreignungsprüfung. Blutalkohol 41: 31-38 (2004).

3. T. Daldrup, H. Käferstein, H. Köhler, R.D. Maier and F. Mußhoff Entscheidung zwischen einmaligem/gelegentlichem und regelmäßigem Cannabiskonsum. Blutalkohol 37: 39-47. (2000).

4. Society of Hair Testing. Recommendations for hair testing in forensic cases. Forensic Sci. Int. 145: 83-84 (2004).

5. F. Mußhoff, H. Sachs and Thieme D. Anlagen zu den Richtlinien der GTFCh bei forensisch-toxikologischen Untersuchungen. Anhang B: Qualitätsstandards für spezielle Analyte. 2. Untersuchung von Haarproben. Toxichem + Krimtech 71: 140-145 (2004).

6. Consensus de la Société Française de Toxicologie Analytique, décembre 2004. Restitution du permis de conduire : examens biologiques à partir de cheveux. http://www.sfta.org.

7. M.R. Moeller, G. Doerr and S. Warth. Simultaneous quantitation of delta-9-tetrahydrocannabinol (THC) and 11nor-9-carboxy-delta-9-tetrahydrocannabinol (THC$\mathrm{COOH}$ ) in serum by GC/MS using deuterated internal standards and its application to a smoking study and forensic cases. J. Forensic Sci. 37: 969-983 (1992).

8. S. Steinmeyer, D. Bregel, S. Warth, T. Kraemer and M.R. Moeller. Improved and validated method for the determination of Delta(9)-tetrahydrocannabinol (THC), 11 hydroxy-THC and 11-nor-9-carboxy-THC in serum, and in human liver microsomal preparations using gas chromatography-mass spectrometry. J, Chromatogr. B Analyt. Technol. Biomed. Life Sci. 772: 239-248 (2002)

9. T. Nadulski and F. Pragst. Simple and sensitive determination of the cannabinoids THC, CBD and CBN in hair samples by silylation, headspace solid phase microextraction and GC-MS. In: Pragst F., Aderjan R. (Eds.): Proceedings of the XIVth GTFCh Symposium, April 1416, 2005 in Mosbach/Baden, Dr. Dieter Helm Ed., Heppenheim 2005, in press.

10. Information of "Bund gegen Alkohol und Drogen im Straßenverkehr",http://www.bads.de/Drogen/cannabis.ht m. September 20, 2005.

11.Landeskoordinierungsstelle Suchtvorbeugung NRW: Zahlen zu Cannabis, http://www.ginko-ev.de/zahlen/zahlen_cannabis.aspx. September 20, 2005. 